\title{
Screening of Garlic Genotypes for Yield and Yield attributing Traits against Stemphylium Blight
}

\author{
Chandan Kumar Bagchi ${ }^{1 *}$, Dayanidhi Chaubey², Sangeeta Shree ${ }^{1}$, \\ Mohammad Ansar ${ }^{3}$ and Avinash Sarin Saxena ${ }^{4}$ \\ ${ }^{1}$ Department of Horticulture (Vegetable \& Floriculture) Bihar Agricultural University, \\ Sabour (Bhagalpur)- 813210 , India \\ ${ }^{2}$ KVK, Purnea (Bihar)- 854327 \\ ${ }^{3}$ Department of Plant Pathology, ${ }^{4}$ Department of Soil Science and Agricultural Chemistry, \\ Bihar Agricultural University, Sabour (Bhagalpur)- 813 210, India \\ *Corresponding author
}

\begin{tabular}{|l|}
\hline K e y w o r d s \\
Bulb quality, \\
$\begin{array}{l}\text { Genotypes, Cloves, } \\
\text { Percent disease } \\
\text { index (PDI) }\end{array}$ \\
\hline Article Info \\
\hline $\begin{array}{l}\text { Accepted: } \\
\text { 15 December } 2019 \\
\text { Available Online: } \\
\text { 20 January } 2020\end{array}$ \\
\hline
\end{tabular}

\section{A B S T R A C T}

Present field experiment was conducted during Rabi seasons of 2016-17 at research farm of BAU, Sabour to study the screening of the best genotype of garlic for yield and yield attributing traits against Stemphylium Blight in Agro-climatic zone IIIA of Bihar. Garlic (Allium sativum L.) is considered as one of the most important species in the family Alliaceae and as an important bulb crop next to onion. It is attacked by a number of diseases of which, in field condition, stemphylium blight is the most economically important diseases. The results revealed that, the maximum plant height $(49.04 \mathrm{~cm})$ was recorded in genotype BRG-13 and lowest $(34.49 \mathrm{~cm})$ in RG-463. The maximum number of leaves per plant was observed in WG-73 (9.22) and minimum in BRG-3 (6.57). The maximum length was recorded in genotype $507(42.91 \mathrm{~cm})$ and minimum length $(31.35$ $\mathrm{cm}$ ) of leaf was found in genotype 569. The maximum breadth of leaf was obtained in genotype BRG-10 $(1.52 \mathrm{~cm})$ and minimum in the genotype $507(0.98 \mathrm{~cm})$. Genotype 644 had thick neck $(0.81 \mathrm{~cm})$ and less thicker neck was obtained in genotype $\mathrm{G} 323(0.80 \mathrm{~cm})$. The minimum was recorded with the genotype IC $375005(2.23 \mathrm{~cm})$ and maximum polar diameter of bulb with genotype WG-73 $(3.35 \mathrm{~cm})$. The highest and lowest equatorial diameter of bulb was recorded with genotype BRG-13 $(4.79 \mathrm{~cm})$ and IC-375005 $(2.74 \mathrm{~cm})$ respectively .The longest clove length recorder in genotype BRG-13 $(2.36 \mathrm{~cm})$ while smallest clove was observed in genotype G-50 $(1.93 \mathrm{~cm})$. Genotype 650 produced thickest clove $(0.98 \mathrm{~cm})$ while BRG-13 was thinnest clove $(0.78 \mathrm{~cm})$. The maximum number of cloves per bulb was recorded in genotype BRG-3 $(52.03 \mathrm{~cm})$ and minimum was in $4(15.48$ $\mathrm{cm})$. The maximum average weight of cloves was observed in BRG-8 $(1.60 \mathrm{~g})$, while the minimum average weight of cloves was exhibited in BRG-7 $(0.39 \mathrm{~g})$. The higher bulb yield per plant was obtained in line BRG-13 (34.65 g) and, while the lowest bulb yield was found in G-1 (20.63 g). The least percent disease index of Stemphylium blight was recorded in genotype BRG-13 $(10.55 \%)$ and, while the highest percent disease index of Stemphylium blight was found in BRG-3 (48.71\%). 


\section{Introduction}

Garlic (Allium sativum L.) is one of the most important bulb crops grown and used as a spice or a condiment throughout India as well as apart of it. It is grown throughout the world and used as spices and flavouring agent for many delicious foods (Velisek et al., 1997). The area under garlic cultivation in India is 280.95 thousands hectares producing 1617.34 thousands metric tonnes with an average national productivity of 5.76 tonnes/ha. In Bihar the area, production and productivity are 4.25 thousands ha, 4.00 thousands metric tonnes and $0.94 \mathrm{t} / \mathrm{ha}$ (DOGR, 2015-16). It is mostly used for culinary purposes and as a condiment for different food items. It is also chiefly used for pungent flavouring and seasoning vegetable dishes. This cash crop is one of the important foreign exchange earner crops of India because of the good quality and quantity of garlic exported every year from the country. Garlic bulb is the most commonly used part of the plant.

With the exception of the single clove types, garlic bulbs are normally divided into numerous fleshy sections called cloves. Garlic cloves are used for consumption (raw or cooked) or for medicinal purposes. More recently, it has been found from a clinical trial that a mouthwash containing 2.5per cent fresh garlic shows good antimicrobial activity, although the majority of the participants reported an unpleasant taste and halitosis (Groppo et al., 2007).

Garlic cloves are used as a remedy for infections (especially chest problems), digestive disorders, and fungal infections such as thrush. Garlic can be used as a disinfectant because of its bacteriostatic and bactericidal properties (Lemar et al., 2005). It is a rich source of protein, phosphorus, calcium, magnesium, potash and ascorbic acid.
Garlic is grown a under wide range of climatic condition. However, it cannot with stand too hot or too cold temperature. It requires cool and moist period during growth and relatively dry period during maturity of bulb. It is also affected by many diseases caused by fungi, bacteria, nematode and viruses but Stemphylium blight is the major and serious disease affecting the productivity adversely. It is caused by a fungus species Stemphylium vesicarium (Wall). It is a foliar disease of garlic and it was reported in Kullu, Himanchal Pradesh during 1997 (Singh and Sharma). The pathogen survives in infected plant debris. A foliar infection up to 90 per cent has been reported in susceptible cultivar of garlic (Bisht and Agrwal, 1993). Leaves being the only photosynthetic organ directly affect the bulb yield. Significant reduction in bulb yield (25-60 per cent) has been observed. The foliar diseases that appear in a severe form are Stemphylium leaf blight and Alternaria leaf blight. The severity of disease is much more where crop is predisposed by thrips injury. Stemphylium leaf blight appears every year in a moderate to severe form in garlic growing areas of Bihar. Severe outbreak of leaf blight of garlic was reported from Bihar during 1995 on varieties Vanarshi and P-49 (Patna selection), ranging the disease severity from 25.6 to $76 \%$ and 20.16 to $75 \%$ respectively (Anon. 2013a). The symptoms of this disease is characterized by small, light yellow to brown and water soaked lesions, which develops on all ages of leaves especially on older leaves. These small lesions grow into enlarged spots that frequently coalesce resulting in blighting of leaves. In advanced stages lesions may girdle and kill leaves. This disease adversely affects the garlic production in other states too particularly Bihar. Thus in spite of being a disease of significant importance, no detailed study on Stemphylium blight has been conducted so far. Since it is an important limiting factor for garlic production, 
comprehensive studies on disease development, its severity and management are essential. Screening is the first step towards resistance breeding. Selection of resistant / tolerant variety is a viable option for managing these diseases.

\section{Materials and Methods}

Field evaluation of thirty eight genotypes were selected out of the collections maintained at the Department of Horticulture (Vegetable and Floriculture) BAU, Sabour during the rabi season of 2016-17 (Table 2). The experiment was laid out in randomized block design (RBD) with 38 treatments replicated three times and situated at $15^{\circ} 40^{\prime} \mathrm{N}$ latitude, $87^{\circ} 2$ ' $42^{\prime}$ 'E longitude and at an altitude of 46 meter above mean sea level. The climate of the experimental site is tropical to sub-tropical with slight semi-arid nature and is characterized by very dry summer, moderate rainfall and very cold winter. Meteological data was procured from the Agro- observatory meterological department of the university.

The crop was planted in the third week of October at a spacing of $15 \mathrm{~cm} \times 10 \mathrm{~cm}$. The recommended dose of fertilizers $\mathrm{N}, \mathrm{P}_{2} \mathrm{O}_{5}$ and $\mathrm{K}_{2} \mathrm{O}$ was applied 120,80 and $40 \mathrm{~kg} \mathrm{ha}^{-1}$ in the form of urea, diammonium phosphate and muriate of potash, respectively was applied. One third dose of nitrogen was applied along with full dose of phosphorous and potash at the time of final field preparation and remaining dose of nitrogen was applied in two split doses as top dressing at an interval of one month from date of sowing. A random sample of ten plants of each cultivar was collected from each plot to measure the plant height $(\mathrm{cm})$ and number of leaves per plant, length of leaf $(\mathrm{cm})$, neck thickness $(\mathrm{cm})$, breadth of leaf $(\mathrm{cm})$ at 90-85 days after planting. However, diameter of bulb $(\mathrm{cm})$, Equatorial diameter of bulb $(\mathrm{cm})$, Length of clove $(\mathrm{cm})$, diameter of clove $(\mathrm{cm})$, number of clove per bulb, average weight of clove $(\mathrm{g})$ and Yield per plant $(\mathrm{g})$ were recorded at the time of harvesting. The data were analyzed statistically by applying ANOVA technique of randomized block design (RBD) as suggested by Panse and Sukhatme (1967).

Screening was done on 0-9 point rating scale based on leaf area covered by the pustules (Mayee and Datar, 1986). Five plants at bulb developmental stage were randomly selected for scoring the disease at fortnightly intervals. Percent disease index (PDI) was calculated on the basis of rating scale and the total number of plants observed as given below.

P.D.I. $(\%)=$

Sum of rating (0-9 scale) $\times 100$

Maximum possible score $\mathrm{x}$ No. of leaves examined

\begin{tabular}{|c|c|}
\hline Grade & Per cent area covered (leaf) \\
\hline $\mathbf{0}$ & Absolutely free from infection \\
\hline 1 & $\begin{array}{l}\text { Small sized lesions on the leaf } \\
\text { covering }<1 \% \text { Area }\end{array}$ \\
\hline 2 & $\begin{array}{l}\text { Small sized lesions on the leaf } \\
\text { covering }<2-5 \% \% \text { Area }\end{array}$ \\
\hline 3 & $\begin{array}{l}\text { Small sized lesions on the leaf } \\
\text { covering }<6-10 \% \% \text { Area }\end{array}$ \\
\hline 4 & $\begin{array}{l}\text { Small sized lesions on the leaf } \\
\text { covering }<11-15 \% 1 \% \text { Area }\end{array}$ \\
\hline 5 & $\begin{array}{l}\text { Small sized lesions on the leaf } \\
\text { covering }<16-25 \% \text { Area }\end{array}$ \\
\hline 6 & $26-40 \%$ area covering \\
\hline 7 & $41-60 \%$ area covering \\
\hline 8 & $61-75 \%$ area covering \\
\hline 9 & $\begin{array}{l}>75 \% \text { area covered with spot, most of } \\
\text { the leaves dried }\end{array}$ \\
\hline
\end{tabular}

\section{Results and Discussion}

The ANOVA for all the traits under study revealed that the mean square estimates due to genotypes were highly significant for all the 
characters studied (Table.1). In other words, the performance of the genotypes with respect of these characters was said to be statistically different; suggesting that, there exists abundant scope for selection in different traits for garlic genotypes improvement. In the present Study, the selection of thirty eight desirable genotype is primarily based on mean performance.

On the basis of the performance mean data (Table 1), the maximum plant height was observed in genotype BRG-13(49.04 cm) followed by genotype $644(45.11 \mathrm{~cm})$ and the minimum was recorded in RG-463 (34.49 $\mathrm{cm})$. Similar variability trend for plant height was also observed by Mathur et al., (1985); Nurzynska-Wierdak (1997); Kohli and Prabal (2000), and Sengupta et al., (2007) in garlic. The maximum leaf length $(42.91 \mathrm{~cm})$ was recorded in genotype 507 which was comparable to BRG-8 (42.38 cm), WG 471 $(41.34 \mathrm{~cm}), \quad$ G323 $(40.92 \mathrm{~cm}), \quad$ WG-73 $(41.51 \mathrm{~cm})$, WG-35 $(41.27 \mathrm{~cm})$, BRG7 (40.99 $\mathrm{cm})$ and BRG10 $(41.17 \mathrm{~cm})$. However, the lowest leaf length was noted in 569 (31.35 $\mathrm{cm})$ followed by BRG- $14(32.15 \mathrm{~cm})$ and 644 $(32.19 \mathrm{~cm})$. Similar results was finding by Kohli and Prabkal (2000) and Sengupta et al., (2007). The highest number of leaves was exhibited in line WG-73(9.22) which was statically at par with genotypes 650 (9.00), 644 (8.76), BRG-10 (8.61), BRG-13 (8.64), BRG-8 (8.61), G-323(8.72), BRG-14 (8.74), RG464 (8.71), 507 (8.50), G-1 (8.48), G-282 (8.66), IC-375005 (8.63) and WG-39 (8.67) while, it was the lowest in BRG-3(65.7) followed by WG-38 (6.97) WG-376 (7.25). . These results are in agreement with the works of Mehta and Patel (1985), NurzynskaWierdak (1997) and Sengupta et al., (2007). The highest breath of leaf was recorded in genotype BRG-10 $(1.52 \mathrm{~cm})$ and narrow in genotype $507(0.98 \mathrm{~cm})$. The results are in close approximation of results of Kohli and Prabal (2000) and Sengupta et al., (2007).
Brewster et al., (1986) also reported that bulb yield depends critically on leaf area index established during bulb development in garlic crop. Higher bulb yield in genotypes with higher leaf area index might be attributed to their ability for higher net assimilation rate resulting into higher production of photosynthates. The genotype $650(0.98 \mathrm{~cm})$ was observed maximum equatorial diameter of bulb while, the minimum diameter of bulb was recorded in line IC-49387 $(0.78 \mathrm{~cm})$. These results of Lommerink (1989); Pandey et al., (1996); Sood et al., (2000),) and Sengupta et al., (2007) are in close accord with the result of the present investigation in garlic crop. The maximum polar diameter of bulb was recorded in genotype WG-73 $(3.55 \mathrm{~cm})$ and the minimum in IC 375005 $(2.53 \mathrm{~cm})$. The results of present study are quite similar with research of Pandey et al., (1996); Kohli and Prabal (2000); Sood et al., (2000) and Sengupta et al., (2007). The maximum neck thickness was recorded in genotype BRG-73 $(0.81 \mathrm{~cm})$ and the minimum in WG-48(0.58cm). Similar findings have been observed by Singh et al., (2015) and Mishra et al., (2013) in garlic.

The longest clove length recorded in genotype BRG-13 $(2.36 \mathrm{~cm})$ while smallest clove was observed in genotype G-50 (1.93 cm). Genotype 650 produced thickest clove $(0.98$ $\mathrm{cm})$ while BRG-13 was thinnest clove $(0.78$ $\mathrm{cm})$. The maximum number of cloves per bulb was recorded in genotype BRG$3(52.03 \mathrm{~cm})$ and minimum was in $4(15.48 \mathrm{~cm})$. Similar, finding has been reported by Pandey et al., (1996), Kohli and Prabal (2000), Shri (2002-2003) in garlic. The maximum average weight of cloves was observed in BRG-8 $(1.60 \mathrm{~g})$, while the minimum average weight of cloves was exhibited in BRG-7 (0.39 g). The results of present study are quite similar with research of Lammerink (1989), Nurzynska Wierdak (1997), Kohli and Prabal (2000) in garlic crop. 
Table.1 Mean performance of different garlic genotype for different traits

\begin{tabular}{|c|c|c|c|c|c|c|c|c|c|c|c|c|c|c|}
\hline No & Character/genotype & PH & NLe & LLe & BrLe & NkT & PoDB & EDB & LC & DC & NCB & AWC & $\mathbf{Y} / \mathbf{P}$ & PDI \% \\
\hline 1 & BRG-10 & 38.61 & 8.61 & 41.17 & 1.52 & 0.78 & 2.89 & 4.01 & 2.10 & 0.91 & 48.50 & 0.56 & 32.12 & 31.28 \\
\hline 2 & BRG-3 & 41.73 & 6.57 & 37.13 & 1.32 & 0.70 & 3.07 & 3.30 & 2.19 & 0.78 & 52.03 & 0.51 & 28.73 & 48.71 \\
\hline 3 & 569 & 42.36 & 7.72 & 31.35 & 1.29 & 0.74 & 3.07 & 4.64 & 1.99 & 0.84 & 21.49 & 1.45 & 31.65 & 24.78 \\
\hline 4 & 644 & 45.11 & 8.76 & 32.19 & 1.48 & 0.72 & 3.16 & 4.76 & 1.99 & 0.96 & 35.63 & 1.06 & 34.18 & 21.60 \\
\hline 5 & 650 & 42.06 & 9.00 & 32.74 & 1.33 & 0.67 & 3.23 & 3.28 & 2.18 & 0.98 & 37.51 & 0.74 & 31.73 & 46.15 \\
\hline 6 & BRG-1 & 37.55 & 8.02 & 40.43 & 1.16 & 0.79 & 2.92 & 3.30 & 2.01 & 0.91 & 19.48 & 1.41 & 27.88 & 42.59 \\
\hline 7 & IC-290440 & 40.65 & 8.33 & 38.37 & 1.34 & 0.75 & 2.98 & 4.05 & 2.18 & 0.85 & 36.52 & 0.80 & 29.54 & 20.21 \\
\hline 8 & BRG-8 & 40.52 & 8.61 & 42.38 & 1.03 & 0.70 & 3.09 & 3.14 & 2.29 & 0.84 & 17.05 & 1.60 & 27.81 & 41.45 \\
\hline 9 & BRG-13 & 49.04 & 8.64 & 33.68 & 1.33 & 0.81 & 3.16 & 4.79 & 2.36 & 0.98 & 46.84 & 0.73 & 34.65 & 10.55 \\
\hline 10 & 4 & 38.01 & 8.33 & 40.48 & 1.33 & 0.64 & 3.14 & 3.49 & 2.30 & 0.95 & 15.48 & 1.34 & 25.78 & 25.60 \\
\hline 11 & WG-471 & 35.04 & 8.39 & 41.34 & 1.21 & 0.75 & 2.94 & 4.09 & 2.10 & 0.95 & 35.62 & 0.72 & 26.77 & 25.73 \\
\hline 12 & WG-7 & 38.11 & 8.26 & 37.89 & 1.36 & 0.69 & 2.96 & 3.47 & 2.17 & 0.91 & 25.06 & 0.99 & 25.06 & 43.92 \\
\hline 13 & G-323 & 38.52 & 8.72 & 40.92 & 1.18 & 0.80 & 3.18 & 4.09 & 2.27 & 0.92 & 20.81 & 1.27 & 26.93 & 39.63 \\
\hline 14 & BRG-9 & 38.20 & 7.96 & 38.44 & 1.43 & 0.74 & 3.10 & 3.41 & 2.21 & 0.88 & 44.47 & 0.59 & 29.31 & 24.53 \\
\hline 15 & BRG-14 & 42.25 & 8.74 & 32.15 & 1.36 & 0.69 & 3.13 & 4.65 & 2.19 & 0.95 & 36.99 & 0.86 & 32.68 & 12.32 \\
\hline 16 & WG-73 & 39.84 & 9.22 & 41.51 & 1.32 & 0.77 & 3.35 & 3.40 & 2.14 & 0.96 & 20.70 & 1.31 & 27.76 & 38.31 \\
\hline 17 & M-175 & 37.19 & 8.24 & 38.34 & 1.13 & 0.66 & 2.95 & 3.81 & 1.93 & 0.86 & 38.45 & 0.54 & 23.86 & 28.82 \\
\hline 18 & 553 & 39.17 & 8.29 & 39.24 & 1.25 & 0.77 & 3.13 & 4.21 & 2.11 & 0.91 & 42.10 & 0.61 & 27.03 & 40.11 \\
\hline 19 & WG-2 & 36.97 & 8.35 & 37.64 & 1.27 & 0.68 & 3.14 & 3.64 & 2.16 & 0.94 & 27.18 & 0.93 & 25.67 & 28.75 \\
\hline 20 & RG-464 & 37.14 & 8.71 & 42.90 & 1.22 & 0.60 & 3.01 & 4.23 & 2.02 & 0.86 & 38.69 & 0.59 & 24.20 & 40.51 \\
\hline 21 & WG-7 & 39.48 & 8.34 & 39.06 & 1.52 & 0.73 & 3.16 & 3.73 & 2.12 & 0.87 & 35.26 & 0.76 & 29.28 & 26.75 \\
\hline 22 & 507 & 37.39 & 8.50 & 42.91 & 0.98 & 0.66 & 2.80 & 4.08 & 1.99 & 0.90 & 34.54 & 0.55 & 21.89 & 28.92 \\
\hline 23 & G1 & 35.78 & 8.48 & 40.33 & 1.38 & 0.73 & 2.84 & 4.34 & 2.16 & 0.83 & 24.36 & 0.99 & 26.07 & 31.31 \\
\hline 24 & IC-375107 & 37.57 & 8.08 & 39.42 & 1.52 & 0.68 & 3.03 & 3.98 & 2.08 & 0.89 & 20.20 & 0.72 & 24.65 & 41.40 \\
\hline 25 & IC-345585 & 38.81 & 7.66 & 35.45 & 1.21 & 0.69 & 3.04 & 4.18 & 2.01 & 0.86 & 38.58 & 0.59 & 24.70 & 43.95 \\
\hline 26 & BRG-7 & 37.15 & 7.42 & 40.99 & 1.32 & 0.66 & 3.09 & 3.79 & 2.16 & 0.97 & 50.22 & 0.39 & 22.73 & 26.80 \\
\hline 27 & G- 282 & 37.10 & 8.66 & 40.31 & 1.21 & 0.71 & 3.16 & 3.49 & 2.06 & 0.91 & 20.56 & 1.14 & 24.04 & 30.00 \\
\hline 28 & G-50 & 37.27 & 7.55 & 36.05 & 1.06 & 0.67 & 2.93 & 4.39 & 2.09 & 0.89 & 35.07 & 0.78 & 28.21 & 46.50 \\
\hline 29 & WG-48 & 38.43 & 7.49 & 37.03 & 1.36 & 0.58 & 2.94 & 2.82 & 2.09 & 0.89 & 25.20 & 0.86 & 24.02 & 28.23 \\
\hline 30 & RG-463 & 34.49 & 7.54 & 36.89 & 1.34 & 0.62 & 2.66 & 3.35 & 2.14 & 0.87 & 29.99 & 0.70 & 24.67 & 27.40 \\
\hline 31 & IC-141151 & 34.63 & 7.76 & 39.45 & 1.08 & 0.73 & 2.66 & 4.14 & 2.16 & 0.82 & 26.92 & 0.91 & 26.23 & 23.80 \\
\hline 32 & WG-376 & 37.67 & 7.25 & 37.29 & 1.22 & 0.71 & 2.64 & 2.75 & 1.94 & 0.87 & 27.21 & 0.90 & 26.17 & 24.20 \\
\hline 33 & IC-375005 & 38.12 & 8.63 & 35.51 & 1.30 & 0.65 & 2.53 & 2.74 & 2.18 & 0.88 & 27.76 & 0.74 & 25.76 & 34.60 \\
\hline 34 & WG-38 & 37.01 & 6.97 & 37.09 & 1.41 & 0.66 & 2.54 & 3.14 & 2.13 & 0.93 & 29.61 & 0.72 & 24.01 & 25.51 \\
\hline 34 & WG-35 & 36.01 & 8.37 & 41.27 & 1.50 & 0.62 & 2.98 & 4.50 & 2.04 & 0.84 & 27.43 & 0.73 & 25.31 & 25.00 \\
\hline 36 & GODAVARI & 35.42 & 7.92 & 34.51 & 1.21 & 0.70 & 2.94 & 3.03 & 2.28 & 0.79 & 27.21 & 0.87 & 23.81 & 24.85 \\
\hline 37 & WG-39 & 38.54 & 8.67 & 36.38 & 1.27 & 0.66 & 3.02 & 2.99 & 2.13 & 0.91 & 21.84 & 0.97 & 24.98 & 26.91 \\
\hline 38 & 0TUR 555 & 36.27 & 7.97 & 36.86 & 1.18 & 0.65 & 2.75 & 2.86 & 2.09 & 0.87 & 23.15 & 0.82 & 25.18 & 33.20 \\
\hline
\end{tabular}

Characters and their abbreviation used in table: Plant height in $\mathrm{cm}(\mathrm{PH})$, Number of leaves per plant (NLe), Length of leaves in $\mathrm{cm}$ (LLe), Breath of leaves in $\mathrm{cm}$ (BrLe), Neck thickness in $\mathrm{cm}(\mathrm{Nk})$, Diameter of bulb in $\mathrm{cm}$ (PoDB), Equatorial diameter of bulb in $\mathrm{cm}$ (EDB), Length of clove in $\mathrm{cm}$ (LC), Diameter of clove in cm (DC), Number of clove per bulb (NCB), Average weight of clove (g), Yield per plant in gram (YP), Percent disease index (PDI \%) 
Table.2 List of Genotypes of Garlic used under investigation

\begin{tabular}{|c|c|c|}
\hline S.No. & Garlic genotype & Source \\
\hline 1 & BRG-10 & Local collection maintained at BAU, Sabour \\
\hline 2 & BRG-3 & Local collection maintained at BAU, Sabour \\
\hline 3 & 569 & Line from DOGR maintained at BAU \\
\hline 4 & 644 & Collection from DOGR maintained at BAU \\
\hline 5 & 650 & Collection from DOGR maintained at BAU \\
\hline 6 & BRG-1 & Collection from DOGR maintained at BAU \\
\hline 7 & IC-290440 & Collection from DOGR maintained at BAU \\
\hline 8 & BRG-8 & Local collection maintained at BAU, Sabour \\
\hline 9 & BRG-13 & Local collection maintained at BAU, Sabour \\
\hline 10 & 4 & Collection from DOGR maintained at BAU \\
\hline 11 & WG-471 & Collection from DOGR maintained at BAU \\
\hline 12 & WG-7 & Collection from DOGR maintained at BAU \\
\hline 13 & G-323 & Collection from DOGR maintained at BAU \\
\hline 14 & BRG-9 & Local collection maintained at BAU, Sabour \\
\hline 15 & BRG-14 & Local collection maintained at BAU, Sabour \\
\hline 16 & WG-73 & Collection from DOGR maintained at BAU \\
\hline 17 & M-175 & Collection from DOGR maintained at BAU \\
\hline 18 & 553 & Collection from DOGR maintained at BAU \\
\hline 19 & WG-2 & Collection from DOGR maintained at BAU \\
\hline 20 & RG-464 & Collection from DOGR maintained at BAU \\
\hline 21 & WG-7 & Local collection maintained at BAU, Sabour \\
\hline 22 & 507 & Collection from DOGR maintained at BAU \\
\hline 23 & G1 & Collection from DOGR maintained at BAU \\
\hline 24 & IC-375107 & Collection from DOGR maintained at BAU \\
\hline 25 & IC-345585 & Collection from DOGR maintained at BAU \\
\hline 26 & BRG-7 & Collection from DOGR maintained at BAU \\
\hline 27 & G- 282 & Collection from DOGR maintained at BAU \\
\hline 28 & G-50 & Collection from DOGR maintained at BAU \\
\hline 29 & WG-48 & Collection from DOGR maintained at BAU \\
\hline 30 & RG-463 & Collection from DOGR maintained at BAU \\
\hline 31 & IC-141151 & Collection from DOGR maintained at BAU \\
\hline 32 & WG-376 & Collection from DOGR maintained at BAU \\
\hline 33 & IC-375005 & Collection from DOGR maintained at BAU \\
\hline 34 & WG-38 & Collection from DOGR maintained at BAU \\
\hline 35 & WG-35 & Collection from DOGR maintained at BAU \\
\hline 36 & Godavari & Collection from DOGR maintained at BAU \\
\hline 37 & WG-39 & Collection from DOGR maintained at BAU \\
\hline 38 & Otur 555 & Collection from DOGR maintained at BAU \\
\hline
\end{tabular}


The higher bulb yield per plant was obtained in line BRG-13(34.65 g) which had statistically at par with BRG-14 (32.68 g), 644 (34.18 g) and BRG-10 (32.11 g) while, the lowest yield per plant was obtained in genotype G-1 (20.63g) followed by 507 (21.89 g), RG-464 (24.19 g) and IC-375107 $(24.65 \mathrm{~g})$. Higher bulb yield may be attributed to cumulative effects of number of leaves per plant, length and diameter of bulb, number of cloves per bulb and average weight of cloves. Variation in yield amongst the lines was also reported by Pandey et al., (1996), Nurzynska Wierdak (1997), and Shrivastava et al., (2004) in garlic. The least percent disease index of Stemphylium blight was recorded in genotype BRG-13(10.55\%) followed by BRG-14 (12.32\%), IC-290440 (20.21\%) and $644(21.6 \%)$ and, while the highest percent disease index of Stemphylium blight was found in BRG-3 (48.71\%) which was significantly at par with 650(46.15) and G50(46.50). These findings are similar to the study of Mishra et al., (2009) and Veeraghanti (2017).

In conclusions, all the 38 genotypes were grown in Randomized Block Design with three replications maintaining a spacing of $15 \times 10 \mathrm{~cm}$. A total of 150 plants were maintained in each plot. The recommended agronomic practices were adopted for raising a good garlic crop. Observations were recorded on 13 important morphological and disease parameter, viz. plant height $(\mathrm{cm})$, neck thickness $(\mathrm{cm})$, number of leaves per plant, length of leaf $(\mathrm{cm})$,breadth of leaf $(\mathrm{cm})$ ,yield per plant $(\mathrm{g})$, plolar diameter of bulb $(\mathrm{cm})$,Equatorial diameter of bulb $(\mathrm{cm})$, number of cloves/ bulb, length of clove $(\mathrm{cm})$, diameter of clove $(\mathrm{cm})$,average weight of clove $(\mathrm{g})$, percent disease index (PDI) with respect to Stemphylium blight. The conclusion of this investigation is presented here under.
Significant variations among genotypes were observed for all the traits under study. Genotype BRG-13 produced the highest yield per plant and was statistically at par with the genotypes, BRG-14, 644 and BRG-10. Least disease index per cent was noticed in BRG-13 followed by BRG-14, IC-290440 and 644 . Thus these genotypes may be considered promising with respect to different traits mentioned.

\section{References}

Anonymous (2013) A new disease of garlic Stemphylium blight discovered. http://aripatna.com.> accessed 1 May, 2013.

Bisht I S, Agrawal R C (1993) Susceptibility to purple blotch (Alternaria porri) in garlic (Allium sativum).The Annals of Applied Biology 122: 31-38.

Groppo F, Ramacciato J, Motta R, Ferraresi P, Sartoratto A (2007) Antimicrobial activity of garlic against oral streptococci. Internation Journel Dental Hygiene 5 (2): 109-115

Kohli U K, Prabal S (2000) Variability and correlation studies on some important traits in garlic (Allium sativum L.) clones. Haryanna Journal of Horticultural Science 29 (3\&4): 209211.

Lammerink J (1989) Quality improvements in printanor garlic. New Zealand. Commercial Grower 44 (4): 18-19.

Lemar K M, Passa O, Aon MA (2005) Allyl alcohol and garlic (Allium sativum) extract produce oxidative stress in Candida albicans. Microbiology 151 (10): 3257-65.

Mehta K G, Patel P H (1985) Genetic variability and path analysis in garlic. Madras Agricultural Journel 72 (12): 691-695.

Mayee C D, Datar V V (1986) Phytopathometry Technical Bulletin.1 
(Special Bulletin 3).Marathwada Agricultural University, Parbhani(Maharashtra) pp. 66.

Mishra R K, Verm A, Singh S, Gupta RP (2009) Screening of garlic lines against purple blotch and stemphylium blight. Pest Management in Horticultural Ecosystems15 (2):138-140.

Mishra R K, Prasad K, Pandey S, Gupta RP (2013) Evaluation of garlic accessions for growth, yield, quality and resistance to Stemphylium Blight disease in northern India. The Energy and Resources Institute (TERI), New Delhi 26 (2): 291-296.

Nurzynska-Wierdak, $\quad \mathrm{R} \quad$ (1997) Characterization of winter garlic ecotypes in south onion. Research Crops 3: 142-144.

Panse V G, Sukhatme P V (1967) Statistical methods for agricultural workers, ICAR, New Delhi.pp 152-161.

Pandey U C, Singh J (1989) Performance of new varieties of garlic (Allium sativum L.). Haryana Agricultural University Ressearch Journal 19 (1): 69-71.

Singh B M, Sharma Y R (1997) Occurrence of leaf blight of garlic caused by Stemphylium botryosum in India. Indian phytopathology 30: 272-273.

Sood D R, Chhokar V, Singh J (2000) Studies on growth pungency and flavour characteristics of five varieties of garlic (Allium sativum L.) bulbs during development. Vegetable Science 27 (2): 180-184.

Shri D (2002) Genetic variability and character association in garlic. Progressive Horticulture 34(1):88-91.

Sengupta S K, Dwivedi S K, Dwivedi Y C (2007) Variation in morphological components of growth and productivity of garlic varieties in the conditions of Madhya Pradesh. JNKVV, Research Journal 41 (2): 224-227.

Singh G, Mishra D P, Kumar V, Pandey V P, Singh S (2015) Genetic diversity in genotypes of garlic(Allium sativum L.) for growth, yield and its attributing traits. Bioscience Biotechnology Research Communications 8 (2): 149152.

Velisek J, Kubec R and Davidek J (1997) Chemical composition and classification of culinary and pharmaceutical garlic-based products. Z Lebensem Unters Forsch A204: 161164

Veeraghanti K S, Naik B G, Hegde KT (2017) Screening of onion genotypes against purple blotch. International Journal of pure and applied Biosciences 5 (1): 221-223.

\section{How to cite this article:}

Chandan Kumar Bagchi, Dayanidhi Chaubey, Sangeeta Shree, Mohammad Ansar and Avinash Sarin Saxena. 2020. Screening of Garlic Genotypes for Yield and Yield attributing Traits against Stemphylium Blight. Int.J.Curr.Microbiol.App.Sci. 9(01): 1159-1166. doi: https://doi.org/10.20546/ijcmas.2020.901.130 